\title{
Vermicompost on the production and nutraceutical quality of jalapeño pepper fruits (Capsicum annuum $\mathrm{L}$.) Vermicompost en la producción y calidad nutracéutica de frutos de chile jalapeño (Capsicum annuum L.)
}

\author{
Bernardo Espinosa-Palomeque ${ }^{1}$ (D) Pedro Cano-Ríos $^{2}$ (i) Lilia Salas-Pérez $^{3}$ (D), \\ Gabriela González-Rodríguez ${ }^{1}$ (i) Arturo Reyes-González ${ }^{4}$ (i), \\ Alma Velia Ayala-Garay ${ }^{(\mathbb{D}}$, and Pablo Preciado-Rangel ${ }^{5:}$ (i)
}

\footnotetext{
${ }^{1}$ Universidad Tecnológica de Escuinapa. Camino al Gausimal s/n, al Noroeste de la Ciudad, Col. Centro. 82400 Escuinapa, Sinaloa, México.

${ }^{2}$ Universidad Autónoma Agraria Antonio Narro, Unidad Laguna. Periférico Raúl López Sánchez km 1.5 y Carretera a Santa Fe s/n. 27059 Torreón, Coahuila, México.

${ }^{3}$ Facultad de Contaduría y Administración, Universidad Autónoma de Coahuila. Fco. Javier Mina 150, Luis Echeverría Álvarez Sector Norte. 27085 Torreón, Coahuila, México.

${ }^{4}$ Instituto Nacional de Investigaciones Forestales, Agrícolas y Pecuarias, Campo Experimental Valle de México. Carretera los Reyes-Texcoco km 13.5, Coatlinchán. 56250 Texcoco, Estado de México, México.

${ }^{5}$ Instituto Tecnológico de Torreón. Carretera Torreón-San Pedro km 7.5, Ejido Ana. 27170 Torreón, Coahuila, México.

‡Corresponding author (ppreciador@yahoo.com.mx)
}

\section{SUMMARY}

The vermicompost is used as a source of nutrients and substrate in protected horticulture because it promotes crop production more sustainable. The objective was to evaluate different proportions of vermicompost: sand (VC:S, v:v) on quality and yield of jalapeño pepper produced in greenhouse environments. Five proportions were compared VC:S, 1:1, 1:2, 1:3, 1:4, 1:5 and a control: (Steiner nutrient solution). The experiment was established in a randomized blocks design with ten replications. On average ratio, $\mathrm{VC}: \mathrm{S}$ (1:1) produce highest fruit weight, fruit length, total phenolic compounds, flavonoids, and antioxidant capacity against to control treatment (0:1 VC:S). Those results indicate that $\mathrm{VC}$ is a fertilization alternative to increase nutraceutical fruit quality, without decrease the jalapeño pepper yield.

Index words: organic fertilizers, protected agriculture, Steiner nutrient solution.

Recommended citation

Espinosa-Palomeque, B., P. Cano-Ríos, L. Salas-Pérez, G. GonzálezRodríguez, A. Reyes-González, A. V. Ayala-Garay, and P. PreciadoRangel. 2020. Vermicompost on the production and nutraceutical quality of jalapeño pepper fruits (Capsicum annuum L.). Terra Latinoamericana 38: 795-803.

DOI: https://doi.org/10.28940/terra.v38i4.605

\section{RESUMEN}

El vermicompost es una fuente de nutrientes y sustrato en la horticultura protegida, porque promueve la producción del cultivo más sostenible. El objetivo fue evaluar diferentes proporciones de vermicompost: arena (VC: S, v:v) sobre la calidad y el rendimiento de chile jalapeño producido en condiciones de invernadero. Se compararon cinco proporciones VC:S, 1: 1, 1: 2, 1: 3, 1: 4, 1: 5 y un control: (solución Steiner). El trabajo se estableció bajo un diseño de bloques al azar con diez repeticiones. En promedio, la proporción VC:S (1: 1) produce el mayor peso de fruto, longitud de fruto, fenoles totales, flavonoides y capacidad antioxidante en comparación al tratamiento control (0:1 VC:S). Esos resultados indican que el $\mathrm{VC}$ es una alternativa de fertilización para aumentar la calidad nutracéutica de los frutos, sin reducir la producción del chile jalapeño.

Palabras clave: fertilización orgánica, agricultura protegida, solución nutritiva Steiner

Received: August 01, 2019. Accepted: July 11, 2020 Published in Terra Latinoamericana 38: 795-803. 


\section{INTRODUCTION}

Chili is the oldest and most common vegetable in the world as a food condiment and nutraceutical value, and it also has an important economic value. China is the main producer with more than 17.5 million $\mathrm{Mg}$, and Mexico is second with approximately 2.7 million $\mathrm{Mg}$ (FAOSTAT, 2016). Chili fruit is a source of vitamins (A, E, and C), carotenoids, capsaicinoids, and phenolic compounds with antioxidant properties for the human diet (Korkutata and Kavaz, 2015). Most of these compounds protect the human body against free radicals (Hallmann and Rembialkowska, 2012). Epidemiological studies have shown beneficial effects of antioxidant compounds in cancer prevention, cardiovascular diseases, and neurodegenerative disorders (Hamid et al., 2010).

Beneficial effects of intake antioxidant compounds in human health play also an important role in the shelf life of fruits (Molina-Quijada et al., 2010). In recent years the concern in the study and quantify antioxidant compounds of fruits has increased because of their nutraceutical properties (Paz et al., 2015). There is also a growing tendency of consumers to prefer healthy foods, additives free, safe, and nutritious (Hasperué et al., 2015). A current option to produce high-quality food with a higher content of vitamins, phenolic compounds, sugars, and antioxidant compounds is the organic production, which avoids the use of chemical synthetic products (Pradeepkumar et al., 2017; SalasPérez et al., 2017).

In Mexico, the jalapeño chili is one of the greatest crops regarding the economic value, due to its wide consumption and to its high profitability and high labor demand (Macías et al., 2012). However, for obtaining high fruit yields is necessary to use fertilizers and pesticides in large amounts, thus increasing production costs, creating risk in human health, and causing a negative impact on the environment (Castellanos et al., 2017). To mitigate negative effects of fertilizers and reduce the problem of organic solid waste generated by agricultural production systems in a sustainable manner, one option is to use organic fertilizers such as vermicompost (VC) which is a potential source of i) soluble nutrients (Reyes-Pérez et al., 2017a), ii) enzymes (Álvarez-Solís et al., 2016), iii) bacterial activity (Maji et al., 2017) and iv) production of humic and fulvic acids and phytohormones capable of stimulating growth and crop yield in organic farming systems (Mendes et al., 2012).

Besides, there is evidence that supplying $\mathrm{VC}$ to soils or growth substrates promotes fruit growth and production of various vegetable crops as tomato (Solanum lycopersicum L.) (Márquez-Quiroz et al., 2014), lettuce (Lactuca sativa L.) (Kapoulas et al., 2017), melon (Cucumis melo L.) (Sánchez et al., 2016), and cucumber (Cucumis sativus L.) (Díaz-Méndez et al., 2014), among other species from commercial interest. The VC helps to increase fruit yields as well as the antioxidant activity of chili fruits (Castellanos et al., 2017). However, the incorporation of substrates derived from the decomposition of organic waste, including $\mathrm{VC}$, can cause high salinity and $\mathrm{pH}$ in the root zone. To reduce the negative effects of $\mathrm{VC}$ it is necessary to mix it with inert media such as river sand that is used in crop production without soil, to improve their physical and chemical characteristics avoiding hypoxia and damage salinity, so it can be used as a substrate or component in greenhouse conditions (Díaz-Méndez et al., 2014). In this context, the objective was to evaluate different proportions of vermicompost: sand (VC:S) on yield and nutraceutical quality of chili in plants grown in greenhouse environments.

\section{MATERIALS AND METHODS}

\section{Plant Material and Growth Conditions}

The research was conducted in a greenhouse provided with automatic cooling of the Antonio Narro University located at Torreón, Coahuila, México $\left(25^{\circ} 33^{\prime} 26^{\prime \prime} \mathrm{N}, 103^{\circ} 22^{\prime} 31^{\prime \prime} \mathrm{W}\right.$, at an altitude of $1230 \mathrm{~m}$ ). The study crop was jalapeño chili cv. Hijo de Mitla germinated in polystyrene trays with 200 holes filled with, peat moss (Premier ${ }^{\circledR}$, México) as substrate. These plant trays were covered with black plastic for $72 \mathrm{~h}$ and irrigated every $24 \mathrm{~h}$. The transplant was made 45 days after seed sowing when plants presented average tallness of $150 \mathrm{~mm}$, each plant per pot. The pots were black bags of polyethylene of 500 thickness and $18 \mathrm{~L}$ capacity, filled with different proportions of VC:S, Sand from the river was washed and disinfected using $5 \%$ sodium hypochlorite solution. The bags were located in a double row at $30 \mathrm{~cm}$ from center to center between bags and $1.60 \mathrm{~m}$ between rows, to get plant density of 4.2 plants $\mathrm{m}^{2}$. Crop water requirements 
were provided by manual irrigation, as detailed next. For treatments $\mathrm{T} 1$ to $\mathrm{T} 5$ the average water supply at four days after planting (DAP) was $0.5 \mathrm{~L} \mathrm{day}^{-1}$ pot $^{-1}$, then increased to $1 \mathrm{~L}$ day $^{-1}$ at $40 \mathrm{DAP}$, until it reached $2 \mathrm{~L} \mathrm{day}^{-1}$ after 60 DAP. In the control treatment, pots were watered with the Steiner nutrient solution at an average rate of $0.5 \mathrm{~L} \mathrm{day}^{-1}$ to the four DAP, and the increased to 1 and $2 \mathrm{~L}^{-1 a y}{ }^{-1}$ at 40 and $60 \mathrm{DAP}$, respectively. Tap water showed small salinity and small sodium content (Ayers and Westcot, 1994). The crop season lasted 120 DAP. The weather conditions inside the greenhouse were: maximum and minimum temperature of 32.3 and $17.4{ }^{\circ} \mathrm{C}$, respectively, and relative humidity oscillating between 30 and $70 \%$.

\section{Design of Experiment and Treatments}

The randomized complete block design was used, with ten repetitions, five treatments (T1 to T5) evaluated were proportions of vermicompost:sand (VC:S, v:v) 1:1, 1:2, 1:3, 1:4, 1:5 plus a control (T6) that consisted of $100 \%$ sand with Steiner nutrient solution (Steiner, 1961) with $\mathrm{pH}$ adjusted to 5.5 and electric conductivity to $2.0 \mathrm{dS} \mathrm{m}^{-1}$. The $\mathrm{VC}$ was obtained by biotransformation a mixture of manures (goats, horses, and rabbits, 1:1:1; v:v:v) with Eisenia fetida earthworms during 90 days (Bhat et al., 2015). The chemical analysis of VC is displayed in the next Table 1.

\section{Fruit Yield and Commercial Quality}

In each experimental unit, the yield was estimated considering the number and the weight of the individual fruit per plant. The quality of fruit was evaluated in 15 fruits randomly sampled per plant in every treatment and repetition, by recording individual fruit traits such as weight with a balance (Ohaus $3729^{\circledR}$, México), length, equatorial diameter and pericarp thickness with a vernier (Truper ${ }^{\circledR}$, México) and firmness with a penetrometer (FHT200, Extech Instruments ${ }^{\circledR}$; USA) provided with $3 \mathrm{~mm}$ plunger.

\section{Nutraceutical Quality}

Extract preparation. for nutraceutical quality determination (phenolic compounds, flavonoids, and antioxidant capacity), samples of $2 \mathrm{~g}$ fruit fresh were mixed with $10 \mathrm{~mL}$ ethanol in plastic tubes that were closed with a screw cap. A stirrer type "Stuart" was used to keep mixture stirring for $24 \mathrm{~h}$. After that tubes were centrifuged at $3000 \mathrm{rpm}$ for 5 minutes. The supernatants were extracted for their physical-chemical analysis.

Total phenolic content. was determined using a modified Folin-Ciocalteu method (Esparza et al., 2006). The results were expressed in $\mathrm{mg}$ of gallic acid equivalents per $100 \mathrm{~g}^{-1}$ fresh weight basis (mg GAE $100 \mathrm{~g}^{-1}$ fresh weight).

Total flavonoid content. was determined using the colorimetric method proposed by Zhishen et al. (1999). The results were reported in mg of quercetin equivalents per $100 \mathrm{~g}^{-1}$ fresh weight basis (mg QE $100 \mathrm{~g}^{-1}$ fresh weight).

Antioxidant capacity. was determined based on the Brand-Williams et al. (1995) results were reported in $\mu \mathrm{M}$ Trolox per $100 \mathrm{~g}^{-1}$ of fresh weight $(\mu \mathrm{M}$ Trolox $100 \mathrm{~g}^{-1}$ fresh weight).

Table 1. Chemical characteristic of the vermicompost evaluated as a growth medium in the cultivation of jalapeño pepper under greenhouse conditions.

\begin{tabular}{|c|c|c|c|c|c|c|c|c|c|c|c|c|}
\hline Substrate & $\mathrm{N}$ & $\mathrm{P}$ & $\mathrm{K}$ & $\mathrm{Fe}$ & $\mathrm{Mn}$ & $\mathrm{Cu}$ & $\mathrm{Zn}$ & $\mathrm{Ca}$ & $\mathrm{Mg}$ & MO & $\mathrm{pH}$ & $\mathrm{EC}$ \\
\hline & $\cdots$ & $\cdots$ & $\cdots$ & $-\mathrm{mg} \mathrm{kg}^{-1}$ & $\cdots$ & $\cdots$ & $\cdots$ & \multicolumn{2}{|c|}{ - - meq L $L^{-1}-$} & $\%$ & & $\mathrm{dS} \mathrm{cm}^{-1}$ \\
\hline $\mathrm{VC}$ & 125.1 & 81.8 & 342 & 5.25 & 4.55 & 1.21 & 3.98 & 27.99 & 2.01 & 21.8 & 8.4 & 4.65 \\
\hline S & 3.9 & 10.9 & 91 & 1.52 & 2.56 & 0.44 & 0.87 & 6.01 & 0.2 & 2.01 & 7.85 & 0.92 \\
\hline OR & $>30$ & $>30$ & $>170$ & $2.5-4.5$ & $1-2.5$ & $0.30-1$ & $0.5-1$ & $\dagger$ & $\dagger$ & $>3$ & $6.5-7.5$ & $2-8$ \\
\hline
\end{tabular}

$\mathrm{MO}=$ organic matter; $\mathrm{EC}=$ electrical conductivity; $\mathrm{VC}=$ vermicompost; $\mathrm{S}=$ sand; $\mathrm{OR}=$ optimum range; values recommended by the soil laboratory of the Cooperativa Agropecuaria de la Comarca Lagunera. ${ }^{\dagger}=$ value not indicated. 


\section{Statistical Analysis}

All variables described above were analyzed through ANOVA. In cases where the statistical difference was found, mean comparisons were made applying the Tukey test $(P \leq 0.05)($ SAS, 2004).

\section{RESULTS AND DISCUSSION}

\section{Fruit Yield and Commercial Quality}

Proportions of VC:S showed significant differences in fruit weight, fruit length, and yield $(P<0.05)$, while the equatorial diameter, pericarp thickness, strength, and fruit number the differences were highly significant $(P<0.01)$ (Table 2$)$. The average fruit weight of organic treatments was higher than the control. Also, plants fruits developed in treatment $\mathrm{T} 1$, exceed in $54.02 \%$ the fruits weight respect to the control plants. Organic treatments affected positively plant height, which increases photoassimilates, which allows increasing the fruit weight (Rodríguez et al., 2009). Also is possible that treatments based on VC, assimilates demand, and other phytohormones in apical tissues are reduced, which helps the content of cytokinins and the accumulation of photoassimilates in fruits (Márquez-Quiroz et al., 2014). The fruit weight gotten in treatments with VC (T1 to T5) corresponds to medium size according to the standards of NMXFF-025-SCFI-2014 (NMX, 2014). The results of this variable were similar to found by López-Gómez et al. (2012) and Moreno et al. (2014) who reported greater fruit weight in chilies grown with VC.

Concerning fruit size (length and equatorial diameter) $\mathrm{T} 1$ and $\mathrm{T} 5$ had highest average 7.32 and $2.82 \mathrm{~cm}$, which correspond to first commercial quality fruits (Vázquez-Vázquez et al., 2011), and were highest in 22 and $24 \%$ in length and equatorial diameter to fruits of the control, respectively. The results can be explained due to the high content of potassium and the contribution of other nutrients by VC (Table 1), which ensure proper growth and plant development (ReyesPérez et al., 2017b), also appropriate concentrations increase fruit size (Morón and Alayón, 2014). The length registered was higher than found by Macías et al. (2012) in chili fruits cv. Mitla, from plants fertilized with chicken and cattle manure under open field conditions, the results were slightly lower to fruit length interval, from 8.09 to $8.83 \mathrm{~cm}$, determined by López-Espinosa et al. (2013). On the other hand, the equatorial diameter was 31.16 and $50 \%$ higher than average values reported by Macías et al. (2012), under management conditions already described and Álvarez-Solís et al. (2016) to assess the quality and yield of jalapeño pepper fertilized with Bokashi.

Table 2. Average values of agronomic variables evaluated in Chili jalapeño cv. Hijo de Mitla, after applying vermicompost mixtures with sand, in plants grown under greenhouse conditions.

\begin{tabular}{|c|c|c|c|c|c|c|c|}
\hline Treatment & FW & FL & ED & PT & $\mathrm{F}$ & $\mathrm{FN}$ & $\mathrm{Y}$ \\
\hline & $\mathrm{g}$ & - - - - & $-\mathrm{cm}-$ & $-\ldots$ & $\mathrm{N}$ & & $\mathrm{Mg} \mathrm{ha}^{-1}$ \\
\hline $\mathrm{T} 2$ & $21.00 \mathrm{a}$ & $6.76 \mathrm{ab}$ & $2.79 \mathrm{a}$ & $0.39 \mathrm{ab}$ & $13.64 \mathrm{a}$ & $32.67 \mathrm{bc}$ & $28.84 \mathrm{ab}$ \\
\hline $\mathrm{T} 3$ & $21.21 \mathrm{a}$ & $6.90 \mathrm{ab}$ & $2.69 \mathrm{ab}$ & $0.41 \mathrm{a}$ & $11.65 \mathrm{ab}$ & $27.33 \mathrm{de}$ & $24.48 \mathrm{ab}$ \\
\hline T5 & $21.51 \mathrm{a}$ & $6.36 \mathrm{ab}$ & $2.82 \mathrm{a}$ & $0.37 \mathrm{ab}$ & $13.12 \mathrm{a}$ & $23.67 \mathrm{e}$ & $21.73 \mathrm{~b}$ \\
\hline T6 & $14.29 \mathrm{~b}$ & $6.00 \mathrm{~b}$ & $2.26 \mathrm{~b}$ & $0.27 \mathrm{c}$ & $10.89 \mathrm{~b}$ & $47.00 \mathrm{a}$ & $28.26 \mathrm{ab}$ \\
\hline HSD (0.05) & 6.309 & 1.132 & 0.439 & 0.052 & 2.072 & 4.445 & 8.865 \\
\hline
\end{tabular}


The highest value of pericarp thickness recorded in T3 treatment was $0.41 \mathrm{~cm}$, exceeding $33.33 \%$ of the control treatment (Table 3). The fruits of organic treatments showed a greater pericarp thickness, which is desirable since this feature is directly related to fruit weight (Coelho et al., 2003), also increases the shelf life due to increases firmness of fruits (MenaViolante et al., 2009). The pericarp thickness obtained in treatment T3 was higher than the average of $0.27 \mathrm{~cm}$ found by Berova et al. (2013) when supplied $100 \mathrm{~cm}^{3}$ of VC to the chili crop cv. Gorogled 6. Also, it was slightly lower than the average value of $0.58 \mathrm{~cm}$ reported by López-Espinosa et al. (2013), for pepper fruits using organic fertilizers. The firmness fruit increased 19.93, 20.48, and $25.25 \%$ in treatments $\mathrm{T} 4$, $\mathrm{T} 5$, and $\mathrm{T} 2$, respectively, in comparison to fruits of the control treatment. Fruit firmness increased because of the optimum level of potassium in organic fertilizers. Increased potassium in fruit firmness was related to greater tissue pressure potential. It indicates that potassium levels provided by VC (Table 1) increased fruit firmness (Kumar and Ponnuswami, 2013). This behavior coincides with reported by Aminifard and Bayat (2016) who indicate that firmness is significantly higher in chili fruits from plants fertilized with VC compared to fruits inorganically fertilized plants. Previous results were similar to Singh et al. (2008), who reported the application of $\mathrm{VC}$ at a rate of 2.5 to
$10 \mathrm{Mg} \mathrm{ha}^{-1}$ in the strawberry crop increased firmness fruit compared to inorganic fertilization. On the other hand, firmness value, $13.64 \mathrm{~N}$ obtained in fruits of $\mathrm{T} 2$ treatment was $116.5 \%$ higher than $6.3 \mathrm{~N}$ registered by Palma-Zavala et al. (2009), in chili fruits cv. Mitla conventionally produced. Cooper et al. (1998) indicate that fruits with greater firmness could be more resistant to decay caused by microorganisms, therefore plants fertilized with VC increase not only firmness but also could decrease fruit deterioration.

Yield variations were due to fruit number per plant and not weight thereof (Table 3). The highest yield was recorded in $\mathrm{T} 1$, with $32.54 \mathrm{Mg} \mathrm{ha}^{-1}$, exceeding $11.37 \%$ to the rest of the treatments. The $\mathrm{VC}$ increases organic matter, nitrogen, phosphorus, and phytohormones in the growth medium, which promotes the development and activity of the root system. Well developed root system tends to register higher plant yield (Zuo et al., 2018). The Yield of treatment T1 was superior to reported by Morón and Alayón (2014), who determined values of $17.3 \mathrm{Mg} \mathrm{ha}^{-1}$ of jalapeño cv. Don Benito in an open field with inorganic fertilization. Likewise, the general average yield was $26.63 \mathrm{Mg} \mathrm{ha}^{-1}$, which is $67.38 \%$ more than the yield obtained by Mexican producers whose value was $15.91 \mathrm{Mg} \mathrm{ha}^{-1}$ (SIAP, 2016). Treatments $\mathrm{T} 1$ and $\mathrm{T} 2$, showed increases in yield of 15.14 and $2.05 \%$, respectively, compared with control. The increased yields in $\mathrm{T} 1$ and $\mathrm{T} 2$, compared to T3, T4,

Table 3. Average values of nutraceutical fruit quality evaluated in Chili jalapeño cv. Hijo de Mitla obtained with different vermicompost: sand proportion under greenhouse conditions.

\begin{tabular}{|c|c|c|c|}
\hline Treatment & Total phenols & Flavonoids & Antioxidant capacity \\
\hline & mg de GAE $100 \mathrm{~g}^{-1}$ fresh weight & mg QE $100 \mathrm{~g}^{-1}$ fresh weight & $\mu \mathrm{M}$ Trolox $100 \mathrm{~g}^{-1}$ fresh weight \\
\hline $\mathrm{T} 1$ & $68.60 \mathrm{a}^{\dagger}$ & $106.80 \mathrm{a}$ & $68.12 \mathrm{a}$ \\
\hline $\mathrm{T} 2$ & $56.60 \mathrm{ab}$ & $86.83 \mathrm{ab}$ & $46.84 \mathrm{~b}$ \\
\hline $\mathrm{T} 3$ & $64.60 \mathrm{ab}$ & $93.95 \mathrm{ab}$ & $52.44 \mathrm{ab}$ \\
\hline $\mathrm{T} 4$ & $57.93 \mathrm{ab}$ & $70.15 b$ & $56.08 \mathrm{ab}$ \\
\hline T5 & $56.80 \mathrm{ab}$ & $66.25 \mathrm{~b}$ & $48.10 \mathrm{~b}$ \\
\hline T6 & $49.33 \mathrm{~b}$ & $68.43 \mathrm{~b}$ & $41.90 \mathrm{~b}$ \\
\hline $\operatorname{HSD}(0.05)$ & 16.809 & 32.036 & 18.012 \\
\hline CV $(\%)$ & 12.41 & 16.99 & 15.00 \\
\hline Standard error & 1.83 & 4.02 & 2.24 \\
\hline
\end{tabular}


and T5 may be the result of better physical properties of the substrate by using greater proportions of VC (>30\%) (Sánchez et al., 2016). This effect is because the optimum ratio of VC stimulates the development and crop production (Pradeepkumar et al., 2017), because of slow gradual nutrients liberation, improved physical and chemical properties of the substrate (Salas-Pérez et al., 2017), microorganisms presence (Maji et al., 2017), as well as the contributions of phytohormones and humic acids that accelerate cell division (Mendes et al., 2012).

\section{Nutraceutical Fruit Quality}

Different proportions of VC:S applied to chili cultivation affected the contents of phenolic compounds $(P<0.05)$ and total fruit flavonoids $(P<0.01$, Table 3$)$. The highest phenolic content and total flavonoids were obtained for $\mathrm{T} 1$, with values of $68.60 \mathrm{mg}$ of GAE $100 \mathrm{~g}^{-1}$ fresh weight and $106.80 \mathrm{mg}$ QE $100 \mathrm{~g}^{-1}$ fresh weight, exceeding in 39.06 and $56.07 \%$ to the control treatment, respectively. This result coincides with established by Aminifard and Bayat (2016), who said that phenolic compounds in organic products are higher than conventional products. The synthesis and accumulation of phenolic compounds are a defense mechanism against biotic and abiotic stress (Kim et al., 2010). Also, it is possible that the differences determined for phenolics and total flavonoids could be attributed to salinity caused by VC in the root medium (Grimaldo-Pantoja et al., 2017). Salinity in the medium causes osmotic stress when the free energy of water decreases, reducing water and nutrients absorption. This restriction increases the biosynthesis of secondary metabolites, such as polyphenols, which promote a better nutraceutical fruit quality (Sánchez et al., 2016). On the other hand, total phenolic compounds' values greatly exceeded the mean value of $40.3 \mathrm{mg}$ of AG/100 fresh weight found by Aminifard et al. (2012) chili fruits cv. Red chili. Value of GAE $68.60 \mathrm{mg} 100 \mathrm{~g} \mathrm{~g}^{-1}$ fresh weight recorded for T1, exceeded $119.94 \%$ of the total phenolic content of $31.19 \mathrm{mg}$ of GAE $100 \mathrm{~g}^{-1}$ fresh weight in fruits chili cv. Almuden, whose plants were developed with the application of inorganic fertilizers (Pérez-López et al., 2007).

Antioxidant capacity of chili fruits was significantly affected by proportions of VC:S $(P<0.01)$, values ranged between 41.90 and $68 \mu \mathrm{M}$ Trolox $100 \mathrm{~g}^{-1}$ fresh weight. The highest antioxidant capacity was presented in T1 with a value of $68.12 \mu \mathrm{M}$ Trolox $100 \mathrm{~g}^{-1}$ fresh weight, exceeding at $29.90 \%$ all treatments, while the control showed lowest $(41.90 \mu \mathrm{M})$ antioxidant activity (Table 3). Increases of antioxidant capacity in fruits with organic treatments, maybe due to the presence of phenylalanine in organic fertilizers which is the precursor of several phenolic substances that contribute to increasing total phenolic compounds (Kumar and Ponnuswami, 2013), these compounds present positive correlation with antioxidant activity (Sánchez et al., 2016). Nevertheless, increase on antioxidant activity of chili fruits registered in $\mathrm{T} 1$ derived from the application of VC could be due, according to PreciadoRangel et al. (2015) and Flores et al. (2009) to the high content of soluble salts and nitrogen present in organic fertilizer (Table 1), these chemical characteristics could cause nutritional stress, which promotes plant mechanisms defense and antioxidants production. In general, similar results were reported by other researchers who have found a significant increase in phenolic compounds content and antioxidant capacity of chili when applying organic fertilizers concerning the application of synthetic fertilizers (Aminifard et al., 2012).

Following results presented in this research, $\mathrm{VC}$ in the substrate could be an alternative to obtain fruits with higher phenolic compounds content and better antioxidant activity which is important for public health because it can contribute to protecting from some diseases, besides, vermicompost is friendly with the environment.

\section{CONCLUSIONS}

The vermicompost used as a component substrate medium for plant growth produces favorable effects on the crop chili cv. Hijo de Mitla cultivated under greenhouse conditions in a hydroponic system because it stimulates the fruit quality. The VC:S ratio (1:1) registered highest, total phenolic compounds, and antioxidant capacity compared to the control; those are evidence of the possibility for producing jalapeño pepper in organic substrates. The VC could be a sustainable alternative to be used as a source of nutrients and growth medium to obtain a better nutraceutical quality of pepper fruits, besides contributing to preserve the environment without inorganic fertilizer supply. 


\section{ETHICS STATEMENT}

During the development of the research, all the authors participated with important contributions according to their expertise and with an ethical basis in their proceedings.

\section{CONSENT FOR PUBLICATION}

Not applicable.

\section{DATA AVAILABILITY}

Data sets used or analyzed during the current study are available in their entirety, upon reasonable request to the author by correspondence.

\section{COMPETING INTERESTS}

The authors declare that they have no interests in competition.

\section{FUNDING}

The project, keyed: 38111-425608002-2855, was funded by Universidad Autónoma Agraria "Antonio Narro".

\section{AUTHORS CONTRIBUTIONS}

Conceptualization: Bernardo Espinosa Palomeque, Pedro Cano Ríos. Methodology: Pedro Cano Ríos, Pablo Preciado Rangel. Software: Bernardo Espinosa Palomeque. Validation: Lilia Salas Pérez, Pablo Preciado Rangel. Formal analysis: Pablo Preciado Rangel. Research: Bernardo Espinosa Palomeque. Resources: Lilia Salas Pérez. Data healing: Alma Velia Ayala Garay. Writing, preparation of the original draft: Bernardo Espinosa Palomeque, Pablo Preciado Rangel. Writing, review and editing: Arturo Reyes González. Visualization: Gabriela González Rodríguez. Monitoring: Pablo Preciado Rangel. Project management: Pedro Cano Ríos. Fund acquisition: Pedro Cano Ríos. All authors read and approved the final manuscript.

\section{ACKNOWLEDGMENTS}

The first author thanks the National Council of Science and Technology (CONACYT) for the scholarship awarded for doctoral studies.

\section{LITERATURE CITED}

Álvarez-Solís, J. D., J. A. Mendoza-Núñez, N. S. León-Martínez, J. Castellanos-Albores, and F. A. Gutiérrez-Miceli. 2016. Effect of bokashi and vermicompost leachate on yield and quality of pepper (Capsicum annuum) and onion (Allium сера) under monoculture and intercropping cultures. Cienc. Inv. Agr. 43: 243-252. doi: https://doi.org/10.4067/S071816202016000200007.

Aminifard, M. H., H. Aroiee, M. Azizi, H. Nemati, and H. Z. E. Jaafar. 2012. Effect of humic acid on antioxidant activities and fruit quality of hot pepper (Capsicum annuum L.). J. Herbs Spices Med. Plants 18: 360-369. doi: https://doi.org/10.1080/1 0496475.2012.713905.

Aminifard, M. H. and H. Bayat. 2016. Effect of vermicompost on fruit yield and quality of bell pepper. Int. J. Hortic. Sci. Technol. 3: 221-229. doi: https://doi.org/10.22059/ ijhst.2017.209130.129.

Ayers, R. S. and W. D. Westcot. 1994. Water quality for agriculture. FAO Irrigation and Drainage Paper 29 Rev. 1. Rome. ISBN: 92-5-102263-1.

Berova, M., G. Pevicharova, N. Stoeva, Z. Zlatev, and G. Karanatsidis. 2013. Vermicompost affects growth, nitrogen content, leaf gas exchange and productivity of pepper plants. J. Elem. 18: 565-576. doi: https://doi.org/10.5601/ jelem.2013.18.4.393.

Bhat, S. A., J. Singh, and A. P. Vig. 2015. Potential utilization of bagasse as feed material for earthworm Eisenia fetida and production of vermicompost. Springerplus 4: 1-9. doi: https:// doi.org/10.1186/S40064-014-0780-Y.

Brand-Williams, W., M. E. Cuvelier, and C. Berset. 1995. Use of a free radical method to evaluate antioxidant activity. LWT-Food Sci. Technol. 28: 25-30. doi: https://doi.org/10.1016/S00236438(95)80008-5

Castellanos, J. Z., P. Cano-Ríos, E. M. García-Carrillo, V. OlaldePortugal, P. Preciado-Rangel, J. L. Ríos-Plaza, and J. L. García-Hernández. 2017. Hot pepper (Capsicum annuum L.) growth, fruit yield, and quality using organic sources of nutrients. Compost Sci. Util. 25: S70-S77. doi: https://doi.org/ 10.1080/1065657X.2017.1362673.

Coelho, E. L., P. C. Rezende, F. L. Finger, and A. A. Cardoso. 2003. Qualidade do fruto de melão rendilhado em função de doses de nitrogênio. Bragantia 62: 173-178. doi: http://dx.doi. org/10.1590/S0006-87052003000200001.

Cooper, W., M. Bouzayen, A. Hamilton, C. Barry, S. Rossall, and D. Grierson. 1998. Use of transgenic plants to study the role of ethylene and polygalacturonase during infection of tomato fruit by Colletotrichum gloeosporioides. Plant Pathol. 47: 308316. doi: https://doi.org/10.1046/j.1365-3059.1998.00228.x. 
Díaz-Méndez, H. A., P. Preciado-Rangel, V. P. Álvarez-Reyna, M. Fortis-Hernández, J. L. García-Hernández y E. SánchezChávez. 2014. Producción orgánica y capacidad antioxidante de frutos de pepino. ITEA-Inf. Tec. Econ. Agr. 110: 335-342. doi: https://doi.org/10.12706/itea.2014.021.

Esparza R., J. R., M. B. Stone, C. Stushnoff, E. Pilon-Smits, and A. P. Kendall. 2006. Effect of ascorbic acid applied by two hydrocooling methods on physical and chemical propertier of green leaf lettuce stored at $5{ }^{\circ} \mathrm{C}$. J. Food Sci. 71: S270-S276. doi: https://doi.org/10.1111/j.1365-2621.2006.tb15653.x.

FAOSTAT (Food and Agriculture Organization of the United Nations). 2016. Crops. http://www.fao.org/faostat/en/\#data/ QC (Consulta: octubre 20, 2017).

Flores, P., P. Hellín, A. Lacasa, A. López, and J. Fenoll. 2009. Pepper antioxidant composition as affected by organic, lowinput and soilless cultivation. J. Sci. Food Agric. 89: 22672274. doi: https://doi.org/10.1002/jsfa.3719.

Grimaldo-Pantoja, G. L., G. Niu, Y. Sun, A. Castro-Rocha, E. Álvarez-Parrilla, J. P. Flores-Márgez, B. Corral-Díaz, y P. Osuna-Ávila. 2017. Efecto negativo del riego salino en componentes del rendimiento y fitoquímicos en chile (Capsicum annuum) inoculado con hongos micorrícicos arbusculares. Rev. Fitotec. Mex. 40: 141-149.

Hallmann, E. and E. Rembialkowska. 2012. Characterisation of antioxidant compounds in sweet bell pepper (Capsicum annuum L.) under organic and conventional growing systems. J. Sci. Food Agric. 92: 2409-2415. doi: https://doi. org/10.1002/jsfa.5624.

Hamid, A. A., O. O. Aiyelaagbe, L. A. Usman, O. M. Ameen, and A. Lawai. 2010. Antioxidants: its medicinal and pharmacological applications. Afr. J. Pure Appl. Chem. 4: 142-151.

Hasperué, J. H., L. Lemoine, A. R. Vicente, A. R. Chaves, and G. A. Martínez. 2015. Postharvest senescence of florets from primary and secondary broccoli inflorescences. Postharvest Biol. Technol. 104: 42-47. doi: https://doi.org/10.1016/j. postharvbio.2015.02.015.

Kapoulas, N., A. Koukounaras, and Z. S. Ilić. 2017. Nutritional quality of lettuce and onion as companion plants from organic and conventional production in north Greece. Sci. Hortic. 219: 310-318. doi: https://doi.org/10.1016/j.scienta.2017.03.027.

Kim, G. D., Y. S. Lee, J. Y. Cho, Y. H. Lee, K. J. Choi, Y. Lee, T. H. Han, S. H. Lee, K. H. Park, and J. H. Moon. 2010. Comparison of the content of bioactive substances and the inhibitory effects against rat plasma oxidation of conventional and organic hot peppers (Capsicum annuum L.). J. Agric. Food Chem. 58: 12300-12306. doi: https://doi.org/10.1021/ jf1028448.

Korkutata, N. F. and A. Kavaz. 2015. A comparative study of ascorbic acid and capsaicinoid contents in red hot peppers (Capsicum annum L.) grown in Southeastern Anatolia Region. Int. J. Food Prop. 18: 725-734. doi: https://doi.org/1 $0.1080 / 10942912.2013 .850507$.

Kumar, M. S. and V. Ponnuswami. 2013. Effect of different water regimes and organic manures on quality parameters of noni (Morinda citrifolia). Afr. J. Agric. Res. 8: 3534-3543. doi: https://doi.org/10.5897/ajar2013.7330.
López-Espinosa, S. T., A. Moreno-Reséndez, P. Cano-Ríos, N. Rodríguez-Dimas, V. Robledo-Torres, and C. MárquezQuiroz. 2013. Organic fertilization: An alternative to produce jalapeño pepper under greenhouse conditions. Emir. J. Food Agric. 25: 666-672. doi: https://doi.org/10.9755/ejfa. v25i9.15979.

López-Gómez, B. F., A. Lara-Herrera, A. G. Bravo-Lozano, J. Lozano-Gutiérrez, J. J. Avelar-Mejía, M. Luna-Flores, and J. J. Llamas-Llamas. 2012. Improvement of plant growth and yield in pepper by vermicompost application, in greenhouse conditions. Acta Hortic. 947: 313-317. doi: https://doi. org/10.17660/ActaHortic.2012.947.40.

Macías D., R., R. L. Grijalva C. y F. Robles C. 2012. Respuesta de la aplicación de estiércol y fertilizantes sobre el rendimiento y calidad de chile jalapeño. Biotecnia 14: 32-38.

Maji, D., P. Misra, S. Singh, and A. Kalra. 2017. Humic acid rich vermicompost promotes plant growth by improving microbial community structure of soil as well as root nodulation and mycorrhizal colonization in the roots of Pisum sativum. Appl. Soil Ecol. 110: 97-108. doi: https://doi.org/10.1016/j. apsoil.2016.10.008.

Márquez-Quiroz, C., S. T. López-Espinosa, E. Sánchez-Chávez, M. L. García-Bañuelos, E. De la Cruz-Lázaro, and J. L. Reyes-Carrillo. 2014. Effect of vermicompost tea on yield and nitrate reductase enzyme activity in saladette tomato. J. Soil Sci. Plant Nutr. 14: 223-231. doi: https://doi.org/10.4067/ S0718-95162014005000018.

Mena-Violante, H. G., A. Cruz-Hernández, O. Paredes-López, M. Á. Gómez-Lim y V. Olalde-Portugal. 2009. Cambios relacionados con textura de frutos y mejoramiento de la vida de anaquel por la inoculación de raíces de tomate con Bacillus subtilis BEB-13BS. Agrociencia 43: 559-567.

Mendes, C. B., G. F. Lima, V. N. Alves, N. M. M. Coelho, D. C. Dragunski, and C. R. T. Tarley. 2012. Evaluation of vermicompost as a raw natural adsorbent for adsorption of pesticide methylparathion. Environ. Technol. 33: 167-172. doi: https://doi.org/10.1080/09593330.2011.554890.

Molina-Quijada, D. M. A., L. A. Medina-Juárez, G. A. GonzálezAguilar, R. M. Robles-Sánchez y N. Gámez-Meza. 2010. Compuestos fenólicos y actividad antioxidante de cáscara de uva (Vitis vinifera L.) de mesa cultivada en el noroeste de México. CyTA-J. Food 8: 57-63. doi: https://doi. org/10.1080/19476330903146021.

Moreno R., A., N. Rodríguez, J. L. Reyes, C. Márquez-Quiroz y J. Reyes. 2014. Comportamiento del chile Húngaro (Capsicum annuum) en mezclas de vermicompost-arena bajo condiciones protegidas. Rev. Fac. Cienc. Agrar. Univ. Nac. Cuyo. 46: 97-111.

Morón R., A. y J. A. Alayón G. 2014. Productividad del cultivo de chile jalapeño (Capsicum annuum L.) con manejo orgánico o convencional en Calakmul, Campeche, México. Av. Invest. Agropec. 18: 35-40.

NMX (Norma Mexicana). 2014. NMX-FF-025-SCFI-2014. Productos alimenticios no industrializados para consumo humano - chile fresco (Capsicum spp.) - especificaciones. http://www.economia-nmx.gob.mx/normas/nmx/2010/nmxff-025-scfi-2014.pdf (Consulta: septiembre 02, 2017). 
Palma-Zavala, D. J., A. Quitero-Ramos, J. Jiménez-Castro, R. Talamás-Abbud, J. Barnard, R. Balandrán-Quintana, and F. Solís-Martínez. 2009. Effect of stepwise blanching and calcium chloride solution on texture and structural properties of jalapeño peppers in brine. Food Technol. Biotech. 47: 464-470.

Paz, M., P. Gúllon, M. F. Barroso, A. P. Carvalho, V. F. Domingues, A. M. Gomes, H. Becker, E. Longhinotti, and C. Delerue-Matos. 2015. Brazilian fruit pulps as functional foods and additives: Evaluation of bioactive compounds. Food Chem. 172: 462-468. doi: https://doi.org/10.1016/j. foodchem.2014.09.102.

Pérez-López, A. J., F. M. del Amor, A. Serrano-Martínez, M. I. Fortea, and E. Núñez-Delicado. 2007. Influence of agricultural practices on the quality of sweet pepper fruits as affected by the maturity stage. J. Sci. Food Agric. 87: 20752080. doi: https://doi.org/10.1002/jsfa.2966.

Pradeepkumar, T., B. P. Bonny, R. Midhila, J. John, M. R. Divya, and C. V. Roch. 2017. Effect of organic and inorganic nutrient sources on the yield of selected tropical vegetables. Sci. Hortic. 224: 84-92. doi: https://doi.org/10.1016/j. scienta.2017.04.022.

Preciado-Rangel, P., K. M. García-Villela, M. Fortis-Hernández, R. Trejo Valencia, E. O. Rueda Puente, and J. R. EsparzaRivera. 2015. Nutraceutical quality of cantaloupe melon fruits produced under fertilization with organic nutrient solutions. Cienc. Inv. Agr. 42: 475-481. doi: https://doi. org/10.4067/s0718-16202015000300015.

Reyes-Pérez, J. J., R. Luna-Murrillo, B. Murrillo-Amador, A. Nieto-Garibay, L. G. Hernández-Montiel, E. O. RuedaPuente y P. Preciado-Rangel. 2017a. Uso de vermicompost y compost de jacinto de agua (Eichhornia crassipes) en el crecimiento de col morada (Brassica oleracea). Interciencia 42: 610-615.

Reyes-Pérez, J. J., R. A. Luna-Murillo, M. R. Reyes-Bermeo, Á. J. Yépez-Rosado, F. Abasolo-Pacheco, K. A. EspinosaCunuhay, R. J. López-Bustamante, V. F. Vázquez-Morán, D. Zambrano-Burgos, D. A. Cabrera-Bravo y J. A. TorresRodríguez. 2017b. Uso del humus de lombriz y jacinto de agua sobre el crecimiento y desarrollo del pepino (Cucumis sativus, L). Biotecnia 19: 30-35. doi: https://doi. org/10.18633/biotecnia.v19i2.382.
Rodríguez D., N., P. Cano, U. Figueroa, E. Favela, A. Moreno, C. Márquez, E. Ochoa y P. Preciado. 2009. Uso de abonos orgánicos producción tomate invernadero. Terra Latinoamericana 27: 319-327.

Salas-Pérez, L., J. L. García-Hernández, C. Márquez-Hernández, M. Fortis-Hernández, J. R. Estrada-Arrellano, J. R. EsparzaRivera, and P. Preciado-Rangel. 2017. Yield and nutraceutical quality of tomato fruits in organic substrates. Ecosist. Recur. Agropec. 4: 169-175.

Sánchez H., D. J., M. Fortis H., J. R. Esparza R., J. C. Rodríguez O., E. de la Cruz L., E. Sánchez Ch. y P. Preciado R. 2016. Empleo de vermicompost en la producción de frutos de melón y su calidad nutracéutica. Interciencia 41: 213-217.

SAS Institute. 2004. User's Guide: Mathematical Programming. Version 9.0. SAS Institute. Cary, NC, USA.

SIAP (Sistema de Información Agroalimentaria y Pesquera). 2016. Cierre de la producción agropecuaria. https://www.gob.mx/ siap/prensa/cierre-de-la-produccion-agropecuaia?idiom=es (Consulta: septiembre 06, 2017).

Singh, R., R. R. Sharma, S. Kumar, R. K. Gupta, and R. T. Patil. 2008. Vermicompost substitution influences growth, physiological disorders, fruit yield and quality of strawberry (Fragaria $x$ ananassa Duch.). Bioresour. Technol. 99: 85078511. doi: https://doi.org/10.1016/j.biortech.2008.03.034.

Steiner, A. A. 1961. A universal method for preparing nutrient solution of a certain desired composition. Plant Soil. 15: 134154. doi: https://doi.org/10.1007/BF01347224.

Vázquez-Vázquez, C., J. L. García-Hernández, E. Salazar-Sosa, J. D. López-Martínez, R. D. Valdez-Cepeda, I. OronaCastillo, M. Á. Gallegos-Robles y P. Preciado-Rangel. 2011. Aplicación de estiércol solarizado al suelo y la producción de chile Jalapeño (Capsicum annuum L.). Rev. Chapingo Ser. Hortic. 17: 69-74.

Zhishen, J., T. Mengcheng, and W. Jianming. 1999. The determination of flavonoid contents in mulberry and their scavenging effects on superoxide radicals. Food Chem. 64: 555-559. doi: https://doi.org/10.1016/S03088146(98)00102-2.

Zuo, Y., J. Zhang, R. Zhao, H. Dai, and Z. Zhang. 2018. Application of vermicompost improves strawberry growth and quality through increased photosynthesis rate, free radical scavenging and soil enzymatic activity. Sci. Hortic. 233: 132-140. doi: https://doi.org/10.1016/j.scienta.2018.01.023. 